\title{
A história em jogo: a atuação de Tichel foucault no campo da historiagrafia
}

Durval Muniz de Albuquerque Júnior*

Resumo. Este texto aborda a contribuição dos trabalhos de Michel Foucault para a historiografia, localizando-a na própria maneira como o autor concebe a história, seja do ponto de vista epistemológico, seja do ponto de vista político. Analisa ainda como, no cerne da prática historiográfica de Foucault, está a imagem do jogo, a figuração da sociedade e do passado como campos atravessados pelos movimentos e enfrentamentos das forças sociais e por suas práticas de simulação, de fabricação de saberes e de subjetividades. A história como saber e como vida é jogo, é agonia, é sorte, é mascarada, é desfalecimento, é corte, é sofrimento e é alegria, é riso e é dor.

Palavras-chave: Michel Foucault. Historiografia. Jogo. Poder. Ficção.

Sempre me intrigou o fato de que, durante muito tempo, os historiadores e cientistas sociais brasileiros dedicaram pouca atenção ao carnaval e ao futebol, duas manifestações centrais da cultura do País. Isso talvez tenha ocorrido devido ao modo como a festa

* Durval Muniz de Albuquerque Júnior é professor da Universidade Federal do Rio Grande do Norte.

Anos 90, Porto Alegre, v. 11, n. 19/20, p.79-100, jan./dez. 2004 
A História em jogo: a atuação de Michel Foucault...

e o jogo foram comumente pensados na cultura ocidental, ou seja, como momentos à parte da vida cotidiana, como atividades sem finalidade, improdutivas, opostas à realidade, à seriedade da ordem social; como momentos de atividade voluntária, livre e desinteressada, fruto de atitudes gratuitas, que constituiriam momentos, tempos e espaços apartados da rotina, resultantes de situações ideais, situações artificiais, que não representariam o funcionamento das estruturas normais e fundamentais que dariam sustentação a uma determinada sociedade. A festa e o jogo, portanto, não fariam parte das estruturas nucleares e essenciais de uma dada cultura ou de um dado sistema social, sendo práticas consideradas de divertimento, de alienação ou de inversão da vida social regular.

Mesmo autores como Johan Huizinga (2004) e Roger Caillois (1990), que se dedicaram ao estudo dos jogos, de sua importância para as várias culturas humanas e seu papel no processo de civilização, vão reafirmar a visão idealizada do jogo, constituindo ele um momento à parte da normalidade da vida social. À medida que teriam contribuído para a aprendizagem da obediência a regras, para a observância de limites, para o exercício do cálculo e levado ao autodomínio, à polidez e cortesia nas relações sociais, tais atividades haviam tido um papel civilizador fundamental. Os autores consideram, porém, que o mundo contemporâneo, ao contaminar os jogos, as festas e os esportes com elementos como o interesse, o lucro e a propaganda, estaria desvirtuando o espírito lúdico que presidiria essas atividades. Anunciam, assim, o fim do espírito lúdico e, com ele, a prevalência, nas sociedades contemporâneas, das perversões das atitudes psicológicas que estariam na base de qualquer atividade de jogo, ou seja, a competição, a sorte, a simulação e a vertigem: nessas, a violência substituiria a competição regulamentada (agôn); a superstição ou o abandono da vontade triunfaria sobre a espera ansiosa e passiva pela sorte (alea); a alienação sairia vitoriosa sobre o gosto pela simulação (mimecry); e o gosto pela vertigem seria substituído pelo consumo de drogas e álcool ou pelos esportes de risco (ilinx). 
Mesmo no campo da Filosofia, as reflexões em torno dos temas da festa e do jogo não são muito recorrentes; esses não seriam, então, temas dignos de ser pensados. Tanto na Filosofia clássica, quanto no cristianismo, o jogo sempre é abordado para fazerem-lhe restrições. Ele é considerado apenas um momento de descanso para o retorno renovado ao trabalho ou ao pensamento; ele serve ao bom humor e pode ser aprendizado de autolimitação e moderação, mas pode levar ao desregramento e ao vício. ${ }^{1}$

Para Leibniz (apud Duflo, 1999, p. 25), o jogo era prova da engenhosidade humana e aprendizado da arte de inventar; ele nos ensinaria a pensar, mas sua prática seria uma estima à incerteza e testemunho de um espírito à vontade. Para Pascal, o jogo seria a expressão da necessidade humana de estar em movimento, da necessidade que teria o homem de divertir a si mesmo para esquecer da morte; o jogo seria uma espécie de ebriedade e vertigem que evitaria o tédio, uma forma de agitação para levar ao esquecimento de nosso caráter mortal, seria, portanto, movimento não-essencial, a busca de enganar-se a si mesmo (Pascal, 1963, frag. 417, p.173). É com Kant que o jogo torna-se um tema a ser abordado em Filosofia. Ele é tomado como o aprendizado humano de sua liberdade diante da natureza, como a expressão da autonomia de sua vontade e da razão, como o aprendizado humano de que ele é a sua própria lei, o seu próprio limite. Para o autor, o jogo é o princípio de animação de todo o ser, já que o ser humano seria constituído pelo jogo de nossas faculdades, esse pensado como a união possível que deixaria existir a distinção recíproca de seus elementos; nós, humanos, seríamos produto, portanto, do jogo da concordância e distinção de nossas faculdades (Kant, 1965, p.135). Mas é com Schiller e, posteriormente, com Nietzsche que o jogo deixa de ser insignificante para tornar-se paradigma. ${ }^{2}$ A agonística que este representa passa a ser tomada como fundamento epistemológico e ético da interpretação da vida social e da história humana. O jogo torna-se um modelo de representação do mundo, e a luta, a rivalidade, a emulação e a guerra passam a ser pensadas como a base de todo edifício social, como atividades centrais na elaboração das culturas.

Anos 90, Porto Alegre, v. 11, n. 19/20, p.79-100, jan./dez. 2004 
A História em jogo: a atuação de Michel Foucault...

Tendo uma relação privilegiada com o pensamento de Nietzsche, a obra de Michel Foucault não conta com qualquer título ou texto que aborde o tema do jogo. No entanto, a palavra jogo espalha-se por muitos dos seus escritos e figura em muitas de suas entrevistas e aparições públicas. No texto Nietəsche, a genealogia e a história (Foucault, 1984a, p.23), a palavra jogo aparece em diversas ocasiões, quando Foucault tentar diferenciar a maneira como, normalmente, os historiadores figuram o passado e a relação da história com ele, da forma como Nietzsche e, por extensão, o próprio Foucault, praticavam história e relacionavam-se com os relatos que constituem o que chamamos de memória. A palavra jogo não aparece aí apenas como metáfora, mas como forma de conceber o funcionamento da sociedade, de figurar como se passa a história, um modo de ver o mundo, de pensá-lo e relacionar as empirias e os conceitos. Para Foucault, a história é resultado de jogos múltiplos, de inúmeros afrontamentos entre forças e saberes, é fruto da emergência de uma dispersão de acontecimentos que são conseqüência de embates, que emergem em meio a forças litigantes. Por isso, a história praticada como genealogia "restabelece os diversos sistemas de submissão: não a potência antecipadora de um sentido, mas o jogo casual das dominações" (Foucault, 1984a, p.17).

A prática da história para Foucault recusa, como o faz a genealogia de Nietzsche, a pesquisa das "origens". Se a história é uma competição incessante de forças, nos começos históricos só se encontra o clamor das lutas, o ruído dos enfrentamentos. Os historiadores devem estar atentos não para as causas dos fatos, tomadas como um evento anterior que se desdobra e continua em um posterior, mas para a multidão de elementos que se aproximam e se cruzam num dado momento e que resultam em um acontecimento. No início não estão a unidade e a identidade de uma causa, mas a dispersão dos fatores, a multiplicidade dos elementos, as forças que ingressam em um campo de luta e as matérias de expressão, o arquivo discursivo que essas forças encontram para dar forma às suas reivindicações. "Procurar uma tal origem é tentar reencontrar 'o que era imediatamente', o 'aquilo mesmo' de uma

Anos 90, Porto Alegre, v. 11, n. 19/20, p.79-100, jan./dez. 2004 
imagem exatamente adequada a si; é tomar por acidental todas as peripécias que puderam ter acontecido, todas as astúcias, todos os disfarces; é querer tirar todas as máscaras para desvelar enfim uma identidade primeira" (ibid., p.23). Buscar a origem dos fatos é, então, procurar acabar com a brincadeira dos homens no tempo, é fazer com que eles sejam adequados a si mesmos, idênticos à sua própria definição, é o historiador colocando a bola embaixo do braço e dizendo: acabou o jogo, não brinco mais! O historiador das origens, criança emburrada, o estraga prazeres.

Para Foucault, se o historiador tiver o cuidado de entrar de corpo e alma na história, admitindo que só se faz a história participando de seu próprio jogo, que não se pode escrever a história como um espectador, torcendo da arquibancada, sendo um historiador atleta e não um historiador assistente, se perceber que só se escreve a história suando a camisa, não a olhando de binóculo de um camarote refrigerado, ele aprenderá que "atrás das coisas há 'algo inteiramente diferente': não seu segredo essencial e sem data, mas o segredo que elas são sem essência, ou que sua essência foi construída peça por peça a partir de figuras que lhes eram estranhas" (Foucault, 1984a, p.17). Como a bola de futebol, os objetos e os sujeitos históricos são feitos de múltiplos gomos, da costura às vezes mal feita e aparente, de diferentes temas, enunciados, conceitos, conteúdos, formas. E todos eles têm furos, rachaduras, por onde sempre ameaçam vazar a sua essência de vento. Suas formas enfatuadas e roliças podem, com um simples gesto de corte feito pelo saber do historiador, pela lâmina de sua crítica, tornar-se a lástima de uma bola murcha, traste deixado em escanteio.

Foucault recusa a idéia de que, nas origens, as coisas, o mundo, os homens estavam em estado de perfeição, eram mais autênticos, mais inocentes ou mais puros. A história não é vista como uma trajetória de queda ou, ao contrário, como um percurso que marca uma ascensão. As quedas e levantamentos marcam todo o jogo da história, eles são circunstanciais, acidentais, eventuais, fortuitos, repetitivos, mas não formam um percurso coerente, nem marcam uma continuidade. No corpo a corpo que é a história, no combate

Anos 90, Porto Alegre, v. 11, n. 19/20, p.79-100, jan./dez. 2004 
A História em jogo: a atuação de Michel Foucault...

permanente que move suas forças, nada garante de saída a autenticidade, a inocência ou a perfeição do que irá ocorrer. Colocados em uma arena, que é a sociedade, os homens lutam para atingirem seus objetivos, para realizarem seus projetos, para materializarem seus sonhos e, para isso, escolhem caminhos diversos, se posicionam em diferentes lugares, adotam táticas e estratégias distintas e lançam mão de suas habilidades e de todo o aprendizado que puderam fazer em sua vida, mas o resultado final ninguém pode prever. Se a meta será alcançada, se a vitória virá, isso dependerá do imponderável das múltiplas jogadas, dos inúmeros lances e deslocamentos feitos pelos demais jogadores e, inclusive, do imponderável, do golpe de sorte, do lance mágico que destrói todos os esquemas previamente estabelecidos. Pensar a história como sendo um jogo é, inclusive, contar com a bola entre as pernas, com o gol contra, com o drible desconcertante, com o tento feito com a mão, com o impedimento, com a penalidade.

Por que temos tanta dificuldade em pensar a surpresa, o acaso e o improvável como elementos que fazem parte da vida e do processo histórico? Como narradores do passado, ainda buscamos conformar o tempo e suas cambalhotas a esquemas prévios de interpretação, com seus determinantes e personagens fixos, previsíveis, que jogam sempre da mesma forma, que seguem sempre a rotina já esperada e, que, mecanicamente, desempenham a função designada antes do início do próprio jogo. O historiador, nesses termos, é o técnico retranqueiro, que busca garantir a previsibilidade do imprevisível, profissional da rotina, que odeia a criatividade, o jogador louco, indisciplinado, rebelde; que retira toda a juventude da própria existência, sua capacidade infinita de se tornar diferente do que é, o devir como potência da história.

É preciso saber reconhecer os acontecimentos da história, seus abalos, suas surpresas, as vacilantes vitórias, as derrotas mal digeridas... A história com suas intensidades, seus desfalecimentos, seus furores secretos, suas grandes agitações febris como suas

Anos 90, Porto Alegre, v. 11, n. 19/20, p.79-100, jan./dez. 2004 


\section{Durval Muniz de Albuquerque Júnior}

síncopes, é o próprio corpo do devir. É preciso ser metafísico para lhe procurar uma alma, [um sentido, o anúncio de uma parusia]." (Foucault, 1984a, p.1920).

A história tudo e nada promete; ela é tanto a alegria instantânea, o gozo furioso da vitória, que pode se transformar, em minutos, na desilusão da derrota acachapante, por goleada, como pode ter, inclusive, o rosto sem graça do empate, do zero a zero. Por que nós, historiadores, esperamos sempre falar do grandioso espetáculo, da vitória retumbante, da glória que produz heróis ou anti-heróis? Porque somos incapazes de falar do cotidiano cinza, dos sacrifícios diários, do suor e lágrimas derramados no silêncio de uma concentração ou de um vestiário, da angústia e do sofrimento de um ídolo esquecido, de uma estrela solitária, de um grêmio rebaixado, de um internacional desclassificado.

O historiador, como os fãs enlouquecidos, quer viver das grandezas repetidas, das promessas de grandes decisões e de grandes conquistas. Mesmo quando nos nomeamos historiadores do cotidiano, micro-historiadores ou historiadores dos excluídos, não perdemos nossa mania de grandeza: o moleiro friulano torna-se o representante de uma classe, o representante de nosso humanismo meta-histórico; o rei africano desterrado torna-se o representante de uma etnia em luta por sua libertação; o líder operário é travestido de salvador da humanidade; o triângulo amoroso carioca torna-se representante da resistência operária. ${ }^{3}$ Não conseguimos jogar um jogo rasteiro, não conseguimos olhar para esses personagens da beira do gramado, não conseguimos abordá-los em sua singularidade, em sua maneira muito própria de armar o jogo, de passar a bola, de safar-se das situações de dificuldade. Continuamos pensando o saber e a ciência como práticas que elevam, que vêem de cima mesmo quando dizemos olhar de baixo; queremos sempre as alturas, as excepcionalidades; adoramos as exceções, mesmo quando dizemos estar tratando das regras, das estruturas. Baixemos a bola, tentemos

Anos 90, Porto Alegre, v. 11, n. 19/20, p.79-100, jan./dez. 2004 
A História em jogo: a atuação de Michel Foucault...

pensar que a história também deve olhar para os peladeiros, para os canhotos, para os cabeças-de-bagre, para os pés-murchos que também atuam na história e são responsáveis pelo seu resultado final. Quando responderemos verdadeiramente à provocação de Levi-Strauss, que nos jogou em rosto a nossa vocação para a construção de mitos? ${ }^{4}$

Ver o mundo como jogo é pensá-lo a partir de uma pragmática, é colocar no centro de sua interpretação as práticas humanas, práticas em conflito e que carecem de significação. A história seria fruto das batalhas em torno do poder e da verdade. Em suas ações, os homens entrariam em disputas em torno de domínios, fossem políticos, fossem de conhecimento. Nessas disputas, a linguagem representaria uma das principais armas, pois seria através dela que seriam demarcados espaços de poder, campos de atuação, identidades, lugares de sujeito, domínios de objetos; seria através dela que se estabeleceriam as aproximações e os distanciamentos, os pactos e as exclusões, os nomes e os silêncios que instituem uma ordem social. Como um dos sentidos que guarda a palavra jogo, a sociedade seria um conjunto complexo de relações, de funções, de táticas, de estratégias, de deslocamentos, um conjunto aberto e inumerável em que a imprevisibilidade estaria presente.

Uma história pensada como jogo é aquela aberta às incertezas, em que qualquer teleologia ou previsibilidade são afastadas. Tratase de uma história que prevê o acaso como possibilidade e como agente dos processos sociais; uma história em que cada momento resulta das forças em presença e em luta, sem a atuação externa de nenhuma força transcendente ou metafísica; uma história que apresenta racionalidades apenas parciais, regionais, racionalidade de cada lance e de cada partida, de cada evento e de cada momento, uma história que não apresenta uma racionalidade absoluta ou em todo o seu conjunto; uma história na qual os homens são capazes de inventar respostas novas para os desafios que se lhes apresentam, a cada momento, em cada tempo diferente. Essa é a história pensada, pois é resultado da própria capacidade de ficção, de imaginação humana. Tanto a história vivida quanto a história escrita seriam testemunhas da capacidade infinita de os homens imaginarem novos

Anos 90, Porto Alegre, v. 11, n. 19/20, p.79-100, jan./dez. 2004 
lances, novas narrativas, novos caminhos, novas metas, novos sentidos para suas próprias vidas.

Foucault vai retomar o próprio sentido original da palavra interpretação. Se o saber histórico nasce de um trabalho interpretativo, isso quer dizer que ele surge de uma atividade de simulação, de ficção, de representação, de construção de máscaras que permitem dar um rosto, uma fisionomia, uma presença, uma aparência ao mundo e aos seres. Nesses termos, o historiador recupera o seu parentesco com os vates da antiguidade, que, mais do que contarem uma história, a interpretavam em praça pública, e seu desempenho era fundamental para a própria credibilidade daquilo que testemunhavam. Interpretar os eventos, interpretar os documentos, significa figurar para eles uma inteligibilidade, dar a eles uma forma, tornálos matéria para a construção de uma dada realidade do passado, dotá-los de uma coerência, tramá-los de forma que pareçam desenhar a figura de um passado que emergiria em seu perfil e em sua materialidade. Interpretar o passado é dar vida a suas possíveis figuras, é recontá-lo, é revivê-lo, encarnando-o em seus possíveis rostos, em suas gesticulações factíveis, em seus diferentes disfarces e com suas inúmeras astúcias.

Foucault (1984a, p.26) diz que interpretar "é se apoderar de um sistema de regras, é fazê-las entrar em um outro jogo e submetêlas a novas regras", ou seja, o próprio trabalho interpretativo inscrevese no campo do lúdico, é fazer o jogo dos sentidos, é dotar os discursos de novas significações, é dar-lhes novas máscaras, é deslocá-los de seu lugar consagrado, é inverter o sentido do jogo levado a efeito até então, é brincar com as possíveis alternativas de figuração. Por isso, as figuras de linguagem que mais aparecem nos textos de Foucault são as ironias, as catacreses e os oxímoros, ou seja, aquelas em que as palavras não guardam nenhuma pretensa relação de semelhança com aquilo que pretendem nomear, nas quais o caráter de fabricação, de disparate, de jogo entre os significados e seus pretensos significantes, os discursos e seus supostos referentes, objetos e sujeitos, são admitidos e explicitados de saída.

Anos 90, Porto Alegre, v. 11, n. 19/20, p.79-100, jan./dez. 2004 
A História em jogo: a atuação de Michel Foucault...

Como em todo jogo, o espetáculo, o aparecer, o vir à cena é o próprio ser das coisas, não existindo uma essência que estaria escondida nos vestiários e só apareceria aos noventa minutos de partida, por um suado esforço de interpretação. O jogo, como a história, é o que acontece, só é enquanto acontecimento. Da mesma forma que, a partir das mesmas regras, é possível jogarem-se inumeráveis partidas, a partir dos mesmos dados, muitas interpretações são possíveis, muitas combinações dos mesmos elementos são factíveis. Pode-se, pois, contar inúmeras vezes os mesmos fatos históricos, de diferentes maneiras.

Pensar a história como jogo é pensá-la como atravessada por uma agonística que tem, na luta e na simulação, as atividades principais dos homens. A vida social inexiste sem o conflito, sem a luta pelo poder e sua transformação em representação, em simulação, em sentido, em saber. Todas as culturas humanas seriam produto desses jogos de poder e saber, que, no pensamento de Foucault, guardam pouca relação com o espírito lúdico idealizado de Huizinga e Caillois. Foucault tende a concordar com estes autores sobre a centralidade do lúdico, ou seja, da invenção, da competição, do acaso, da imaginação e da vertigem nas relações entre os homens e na construção da vida social; mas não vê o jogo como uma realidade apartada da ordem social e uma situação ideal, que serviria de modelo para o funcionamento da sociedade e para as relações sociais. $\mathrm{O}$ jogo seria imanente à vida social, seria imanente à história; nos começos de qualquer evento histórico, estaria a dispersão de forças em luta e a posterior elaboração de um sentido, de uma máscara, de uma identidade para aquilo que foi fabricado, para aquilo que emergiu do próprio confronto.

A emergência de um acontecimento se dá sempre em um determinado estado das forças, que devem ser mostradas, pelos historiadores, em seu jogo, a maneira como lutam umas contra as outras, ou seu combate frente a circunstâncias adversas, ou ainda a tentativa que elas fazem - se dividindo - de escaparem da

Anos 90, Porto Alegre, v. 11, n. 19/20, p.79-100, jan./dez. 2004 


\section{Durval Muniz de Albuquerque Júnior}

degenerescência e recobrar o vigor a partir de seu enfraquecimento (Foucault, 1984a, p.23).

Refletir sobre o jogo da história é pensar, a cada vez, que forças entraram em campo em dado evento, que regras produziram ou que regras seguiram no momento de atuarem e como essas forças tornaram-se sujeitos desse acontecimento. Tal reflexão implica ainda pensar que cada sujeito social faz-se sujeito no próprio momento que atua, que joga, que sua existência depende da existência do outro, da relação agônica com o outro, que lhe limita e lhe define como aliado ou como inimigo, pensar que "o grande jogo da história será de quem se apoderar das regras, de quem tomar o lugar daqueles que as utilizam, de quem se disfarçar para pervertê-las, utilizá-las ao inverso e voltá-las contra aqueles que as tinham imposto" (ibid., p.25).

A vida social e a história teriam, para Foucault, as mesmas características que definem o que seria uma atividade de jogo. A história seria movimento, seria ação criativa, invenção constante de novos lances, mesmo que seus sujeitos estejam limitados por regras, por normas, que tenham que obedecer a regulamentos. A história é possível porque os homens, mesmo limitados por um dado contexto, por um conjunto de regras e prescrições, ainda que atuando em um espaço e em um tempo delimitados, são capazes de driblar a potência do mesmo e a imposição da repetição e criarem o diferente, a novidade, de produzirem a surpresa e o inesperado. A história, como o jogo, faz-se de risco e habilidade, de variação e mudança, de limite e invenção, de regras imanentes e de restrições voluntárias.

Foucault pensa a história como mediada, assim como o jogo, por estratégias e táticas, as quais podem estar a serviço da criatividade ou da reação, podem levar à vitória ou serem derrotadas, que podem servir de impedimento ou de incentivo à atuação das forças em luta. A história é feita de disputas em que os contendores tentam alianças e buscam enfrentamentos, em que o domínio das regras, o estabelecimento das regras e a possibilidade de burlá-las ou usá-las

Anos 90, Porto Alegre, v. 11, n. 19/20, p.79-100, jan./dez. 2004 
A História em jogo: a atuação de Michel Foucault...

contra o inimigo é uma constante. Mesmo tendo os homens criado inúmeras instâncias sociais que buscam arbitrar a observância destas regras, a história faz-se como potência criativa, porque essa arbitragem sempre pode ser enganada, ser corrompida, ser ludibriada e usada em proveito das forças em luta.

Assim como um jogo, a história está sempre sendo jogada a cada vez, ela é descontínua mesmo que se faça por repetições e apresente regularidades. Assim como nas partidas de futebol, que seguem sempre as mesmas regras, em que a semelhança do jogo parece garantida, mas o resultado é sempre incerto, em que a combinação das jogadas e os lances nunca se repete, em que cada partida é singular e irrepetível, assim também são os eventos históricos. A história não tem um sentido dado a priori, não tem uma racionalidade e uma finalidade que a atravessam desde o começo; como no jogo, o sentido da história é o seu próprio acontecer. O resultado final de qualquer enfrentamento na história só se define em seu último instante; não há previsibilidade possível, somente probabilidade de que as coisas se passem tal como o esperado.

A escrita da história é concebida por Foucault como a elaboração de um discurso que, como qualquer outro, não está permanentemente submetido ao poder, nem oposto a ele. "É preciso admitir um jogo complexo e instável em que o discurso (historiográfico) pode ser, ao mesmo tempo, instrumento e feito do poder, e também obstáculo, escora, ponto de resistência e ponto de partida de uma estratégia oposta" (Foucault, 1977, p.96). O discurso da história tanto pode veicular e produzir poder, reforçá-lo, como pode vir a miná-lo, debilitá-lo e permitir barrá-lo. Longe está Foucault da análise simplista e grosseira do poder, como uma maquinaria sem saída, que vez por outra tentam atribuir a ele. ${ }^{5}$ Pensar o poder como um elemento fundamental do jogo da história é tomálo como resultante sempre indefinida e indeterminada do embate das forças que compõem um dado campo social, é tomá-lo como sendo materializado em um conjunto de regras e de normas, que estão sempre sendo negociadas, jogadas. Ao invés de um monstro

Anos 90, Porto Alegre, v. 11, n. 19/20, p.79-100, jan./dez. 2004 
cinza, o poder em Foucault aparece em sua dimensão lúdica, brincalhona, estratégica, astuciosa, em sua potência de simulação, mascaramento, inversão e traquinagem.

Há uma grande resistência, entre os historiadores profissionais, em aceitar a maneira como Foucault pratica a história. Acostumados a pensar o processo histórico como uma totalidade coerente e racional, como um processo que possui um princípio de coerência, uma essência ou uma verdade que deve ser buscada, mesmo quando se sabe que dela apenas se pode se aproximar, esses princípios, digamos, morais que o historiador deve seguir são sempre reafirmados. ${ }^{6}$ Ele tem que estar comprometido com a razoabilidade e com a veridicidade do que faz, ou seja, o historiador não deve brincar em serviço, ele seria um mau jogador, um ser sem senso de humor, um homem sério falando de coisas muito sérias. Mas, para uma criança, brincar ou jogar é também algo muito sério, ela está, muitas vezes sem saber, fazendo o aprendizado das próprias regras sociais, está internalizando a sociedade. Também podemos aprender com os jogos da história, com suas brincadeiras e mascaradas, com suas síncopes e seus desfalecimentos. Como em qualquer jogo, na história também se pode sorrir ou chorar, afirmar a vida ou morrer em campo, pode-se ganhar ou perder, mas todos os lances levamnos a um aprendizado, à formulação de uma experiência, que pode novamente ser recolocada em jogo no próximo evento.

Foucault, como Nietzsche, vai procurar recolocar o corpo na história. As ciências humanas, por muito tempo, recusaram-se a tratar do corpo, da materialidade do corpo. Na Filosofia, tínhamos pensamentos e pensadores sem corpo; na História, os personagens não tinham desejo, nem necessidades corporais, não tinham sangue, mesmo participando de tantas guerras e revoluções. Foucault pensa o corpo como a "superfície de inscrição dos acontecimentos (enquanto que a linguagem os marca e as idéias os dissolvem), lugar de dissociação do $\mathrm{Eu}$ (que supõe a quimera de uma unidade substancial), volume em perpétua pulverização" (Foucault, 1984a, p.22). A história genealógica articula corpo e acontecimento, corpo e linguagem, mostrando as marcas e as ruínas que o tempo produz

Anos 90, Porto Alegre, v. 11, n. 19/20, p.79-100, jan./dez. 2004 
A História em jogo: a atuação de Michel Foucault...

em nossas carnes e nas imagens que temos de nós mesmos. A história pensada como jogo põe no centro de nosso campo as peripécias dos corpos, a análise do que eles fazem e de como explicam o que fazem, a descrição de suas atuações, deslocamentos, fraturas, indisposições, choques, atrações, desejos, seduções. São os corpos pensados como documentos, como pergaminhos em que vêm se escrever e inscrever as memórias das múltiplas experiências que vivenciamos.

Por que temos tanta dificuldade em auscultar os corpos dos personagens dos quais tratamos, em tateá-los, massageá-los, como anatomistas do social que devemos ser? Por que fazemos uma história tão higienizada, em que nossos personagens não têm odor, são feitos apenas para serem vistos e não para agradar ou desagradar aos outros sentidos? A história ainda é o lugar do império do olhar, pois ainda continuamos, como os gregos, buscando testemunhos, mesmo quando pretendemos fazê-la para estimular os leitores a deixarem de ser meros espectadores de seu desenrolar. Como poderemos tornar a história um saber sedutor se ela não tem corpo, se seus personagens estão mortos e parecem mesmo com defuntos conservados em formol? Como pode seduzir os vivos algo que não tem vida, que se faz por fórmulas conceituais? No espírito do que escrevia Nietzsche (1991, p.22-34), a história conceitual é uma monstruosidade, é o resfriamento do que é calor e vida, é a mumificação do que foi vivo e quer ainda respirar. Como podemos atrair os leitores da história para personagens que não têm sexo, não desejam, não brincam, não jogam?

Como jogadores que somos, a nossa história não está documentada apenas nas súmulas que escrevemos e que guardamos em arquivos, não está apenas nas resenhas que produzimos a respeito de nossas vidas e ações, mas ela está documentada em cada cicatriz que marca nossos corpos, em cada sinal, em cada tatuagem, em cada escarificação, em cada dor que veio se alojar em nossas peles ou em nossas entranhas. Cada ferida cicatrizada é um monumento a um instante dolorido que passou, é um resto de tempo petrificado. Embora sendo um saber que privilegia o olhar e seus testemunhos, contraditoriamente a história tem tido uma enorme dificuldade em

Anos 90, Porto Alegre, v. 11, n. 19/20, p.79-100, jan./dez. 2004 
lidar com imagens, talvez porque aí apareça o corpo, o incômodo de um corpo, mesmo quando ainda está congelado por um instantâneo de uma máquina fotográfica. O corpo, mesmo em uma pose repetitiva, parece nos amedrontar. Quando ele aparece em movimento, a dificuldade e a estranheza parecem se ampliar. Esses personagens que se movem figuram tão diferentes dos personagens canhestros que conseguimos produzir em nossas narrativas, que nos amedrontam, porque nos interpelam no sentido de sermos capazes de dizer o corpo em movimento, em deslocamento, a identidade arruinada por um simples gesto, o dilaceramento constante daquilo que gostamos de chamar de Eu. Colocados diante de nossa própria imagem, sentimos a desilusão de ver que nunca correspondemos à imagem que temos de nós mesmos, que dirá a imagem que construímos dos outros. Nossas identidades são fruto de um jogo permanente, jogo de esconde-esconde, uma brincadeira de máscaras, num carnaval organizado e submetido a um emaranhado de regras.

Pensar a história como jogo corresponde, em Foucault, a uma postura epistemológica, mas também a uma postura ética. Nos últimos livros que escreveu, Foucault $(1984,1985)$ estava preocupado em entender através de que jogos construímo-nos como o sujeito de uma sexualidade, de uma moralidade. Sua preocupação era procurar pensar o sujeito para além da imposição socráticoplatônica do conhecer a si mesmo. Ele vai deslocar essa questão a partir da pergunta nietzscheana, que era a mesma colocada pelos gregos antes de sua entrada na filosofia racionalista, ou seja: o que estamos fazendo de nós mesmos? A constituição da subjetividade, de uma identidade de sujeito, passa a ter aí uma implicação política imediata. Perguntar pelo quê se está fazendo consigo mesmo é perguntar-se pela forma como se está governando a própria vida, como está se fazendo uso dos prazeres, como se está cuidando de si mesmo e escrevendo a si mesmo, como se está se relacionando com seu próprio corpo e com seus desejos. A construção de nós mesmos passava por esse jogo incessante que jogamos com nós mesmos e com os outros. É a pergunta pelo treinamento que estamos submetendo o nosso próprio corpo e nossa própria mente, que

Anos 90, Porto Alegre, v. 11, n. 19/20, p.79-100, jan./dez. 2004 
A História em jogo: a atuação de Michel Foucault...

exercícios, que dietas, que limites estamos impondo a nós mesmos. Para que sejamos um craque na vida, precisamos desse trabalho de auto-emulação, de autoconstituição, tentando transformar a própria vida na melhor jogada, num gol de placa, numa obra de arte. No lugar do imperativo de conhecer uma essência que estaria guardada no interior de um si mesmo discutível, coloca-se a conclamação para a fabricação de um si mesmo, que nunca está pronto e que nunca pode deixar de ser convocado a se exercitar novamente.

Nós, historiadores, temos muita dificuldade em pensar o sujeito como um exercício, como uma função que se exerce numa ação, num discurso, como algo que não esteja pronto no início da ação, que não venha antes do discurso, mas que seja seu resultado final, sujeito que só aparece já na prorrogação. Estamos sempre buscando o sujeito originário, aquele que deu o pontapé inicial na ação, aquele que começou o jogo, que deu a saída, quando isso pouco importa, pois o jogo ou a história são o que se desenrola daí para frente, e seu resultado independe por completo de quem veio por escalação momentânea ou da posição que o sujeito ocupava ao dar o primeiro piparote no jogo. Sempre alertamos para o fato de que os sujeitos em história são coletivos, de que fazem parte de uma grande equipe, de que na história não se joga sozinho; sempre dizemos que a história, como o jogo, passa-se entre os jogadores, é feita das suas jogadas, de seus lances, mas mesmo assim estamos sempre buscando aquele que, da marca da cal, deu o chute decisivo, cobrou o pênalti salvador, aquele herói que sozinho ganhou o jogo, aquela mão salvadora que, no último instante, desviou a trajetória do balão.

Não desconhecemos que as ações individuais são importantes, que há realmente jogadores mais decisivos que outros, aqueles que fazem a diferença, que abrem espaços para outros, mas, mesmo esses, não conseguiriam atuar sem a colaboração dos demais, pelo simples fato de que, sem outros, não haveria jogo, sem as relações entre os sujeitos e os lugares que essas relações distribuem não haveria história nem sujeitos. Não importa qual o nome próprio de quem vem ocupar a posição de goleiro, de zagueiro ou de atacante, mas a função que exerce no jogo, o papel que lhe é atribuído, o lugar de sujeito ou a

Anos 90, Porto Alegre, v. 11, n. 19/20, p.79-100, jan./dez. 2004 
camisa que lhe tocou envergar; o que importa é a distribuição no campo e o lugar que assume no coletivo que se movimenta. Só nos constituímos em destaque em relação aos demais, só nos individualizamos, nos singularizamos na relação com o outro, só nos reconhecemos e somos reconhecidos como sujeito em confronto com outros que estão ao nosso lado ou à nossa frente; somos sempre, pois, um produto do coletivo.

Da mesma forma que temos dificuldade em pensar os sujeitos da história como imanentes aos próprios acontecimentos, ao próprio jogo das forças e dos saberes que os constituem, temos dificuldade de pensar o objeto histórico, o acontecimento em sua singularidade, em sua fabricação agonística. A tradição teleológica e racionalista que prevalece no campo da historiografia tende a dissolver o acontecimento singular em uma continuidade ideal - como se o campeonato, em sua totalidade, fosse o que determinasse o resultado das partidas que o compõem, como se, entre elas, houvesse previamente uma determinação que definisse os resultados.

A história efetiva faz ressurgir o acontecimento no que ele pode ter de único e agudo. É preciso entender por acontecimento não uma decisão, um tratado, um reino, ou uma batalha, mas uma relação de forças que se inverte, um poder confiscado, um vocabulário retomado e voltado contra seus utilizadores, uma dominação que se enfraquece, se distende, se envenena e uma outra que faz a sua entrada, mascarada. As forças que se encontram em jogo na história não obedecem nem a uma destinação, nem a uma mecânica, mas ao acaso das lutas. Elas não se manifestam como formas sucessivas de uma intenção primordial; como também não têm o aspecto de um resultado. Elas aparecem sempre na álea singular do acontecimento (Foucault, 1984a, p.28).

Foucault tem a coragem de afirmar que a história é um saber perspectivo, ou seja, que as narrativas que fazemos de um dado

Anos 90, Porto Alegre, v. 11, n. 19/20, p.79-100, jan./dez. 2004 
A História em jogo: a atuação de Michel Foucault...

acontecimento têm a nossa própria participação. Nós também entramos no jogo quando se trata de escrever a história. Somos, ao mesmo tempo, narrador e árbitro, técnico e jogador, torcedor e atacante; estamos implicados naquilo que fazemos, nos resultados a que chegamos. Não dá mais para acreditar na encenação de que nós apenas abrimos mão de nossa individualidade para que outros entrem em cena e tomem a palavra. Não dá para levar a sério o jogo de fazde-conta da objetividade e do princípio da verdade atrás do qual nos escondemos para só falarmos de nossas próprias posições políticas e historiográficas como se estivéssemos falando em nome da história ou da razão, da objetividade e dos fatos. Chega de ensaios racionalistas que mal escondem o seu rancor e sua demagogia, como dizia Nietzsche em A Genealogia da Moral.

Eu não posso mais suportar estes eunucos concupiscentes da história, todos os parasitas do ideal ascético; eu não posso mais suportar estes sepulcros caiados que produzem a vida; eu não posso suportar seres fatigados e enfraquecidos que se cobrem de sabedoria e apresentam um olhar objetivo (Nietzsche apud Foucault, 1984a, p.32).

Foucault propõe três usos para a história, três maneiras de praticá-la, que reafirmam essa necessária aceitação do caráter subjetivo e político de nossa atividade. Um deles é o uso paródico ou irônico, que se opõe à história vista como reminiscência ou reconhecimento, propondo uma história praticada como riso, como destruição das versões consagradas da realidade, como produção de um distanciamento entre nós e aqueles que nos antecederam, como reposição diferencial dos saberes, dos discursos que produziram aquilo que achamos que somos. Outro é o uso dissociativo e destruidor da identidade, que se opõe à história como continuidade e tradição, postulando uma história praticada como afastamento da continuidade, como dilaceramento dos modelos de identidade que nos chegam do passado e se impõem como indispensáveis. O terceiro

Anos 90, Porto Alegre, v. 11, n. 19/20, p.79-100, jan./dez. 2004 
é o uso sacrificial e destruidor da verdade, que se opõe à históriaconhecimento, expressando uma história praticada como desconfiança em relação a todas as verdades que nos chegam prontas, a todas as certezas que nos chegam sem questionamento. A história tem assim, para Foucault, todas as características de um saber pensado como jogo, pois ela implica a brincadeira com as máscaras, a violência do embate e do combate, a entrada em cena do acaso e da sorte e o desejo de vertigem, da perda das referências fixas que amarram nossos corpos e mentes a dadas identidades, razões e lugares. A história é agôn, é álea, é mimecry e é ilinx, ou seja, conflito, acaso, simulação e vertigem.

Devemos encarar, pois, a própria luta no campo historiográfico como um jogo em que cada texto, em que cada livro, em que cada opinião é um lance que se faz em uma partida. Encarar os debates historiográficos desse modo talvez nos ajude a torná-los mais divertidos e mais corteses, evitando que eles se transformem em uma guerra de todos contra todos, embates nos quais ferozmente se querem eliminar o contendor e seu pensamento a golpes de adjetivos de desqualificação.

Michel Foucault tem sido vítima sistemática desse tipo de crítica, dentro e fora do País. Quando se trata de avaliar sua contribuição para a historiografia, tem faltado fair play a boa parte dos colegas, e vemos um jogo cheio de caneladas, rasteiras, cotoveladas e entradas desleais. ${ }^{7}$ Todo o seu trabalho no campo historiográfico é desqualificado com meia dúzia de opiniões e palpites, sendo quase sempre atingida sua pessoa e não seu pensamento. Para comentar, é preciso conhecer, regra tão básica em nosso futebol, mas que não é aplicada em nossa academia.

Foucault é sempre tratado como um invasor do campo, como alguém que, inclusive, quis acabar com a história, mesmo que tenha dedicado toda a sua vida a fazê-la e tenha se mostrado um praticante criativo de nosso metier, estimulando uma ampla produção na área. ${ }^{8}$ Tratado como bicão, Foucault seria uma ameaça para a nossa atividade, pois, com ele, a própria história estaria em jogo, nosso sacrossanto saber estaria ameaçado de ser conspurcado e remetido

Anos 90, Porto Alegre, v. 11, n. 19/20, p.79-100, jan./dez. 2004 
A História em jogo: a atuação de Michel Foucault...

para os obscuros domínios do irracionalismo, do esteticismo e do reacionarismo político. Surgem então, como sempre, os salvadores de última hora, que vão evitar que a história sofra essa ameaça e esse rebaixamento. Aqui, como em futebol ou em religião, devemos desconfiar desses enunciadores do caos e do apocalipse, que querem tomar o jogo para si e impor regras que só eles estão dispostos a seguir; o que querem é poder disfarçado de verdade; querem acabar o jogo no momento em que acham que estão ameaçados de serem derrotados. Isso sim é o fim do jogo, é o fim do lúdico, é o fim da possibilidade de invenção e de criação; isso sim é o fim da história. A história morreria não por criatividade, mas por paralisia, por falta de renovação em suas regras de produção. Não é o invasor a maior ameaça ao jogo, mas o que dele participa jogando na retranca, buscando evitar a surpresa e o inesperado; é o que busca torná-lo rotina e mesmice, é o que faz um jogo burocrático e odeia aquele companheiro que brilha e que desconcerta com a magia de sua arte. Michel Foucault é da genealogia dos craques, dos fora de série, daqueles que, mesmo quando são nosso adversário, só nos resta sentar e aplaudir.

\section{History in focus: the role of Michel Foucault in the field of historiography}

Abstract. This text approaches the contribution of Michel Foucault's works to historiography, situating it in his own conception of history, from either epistemological or political point of view. This text analyzes how, in the center of Foucault's practice of historiography, is the image of the game, the representation of society and the past as fields crossed by movements and confrontations of the social forces and by their acts of simulation, production of knowledge and subjectivities. History as knowledge and life is a game, is agony, is luck, is masqued, is faint, is cut, is suffering and joy, is laughter and pain.

Keywords: Michel Foucault. Historiography. Game. Power. Fiction.

Anos 90, Porto Alegre, v. 11, n. 19/20, p.79-100, jan./dez. 2004 


\section{Durval Muniz de Albuquerque Júnior}

\section{Notas}

${ }^{1}$ Cf. Tomás de Aquino, em Suma teológica, e Francisco de Sales, em Introdução à vida devota (apud Duflo, 1999, p. 20-21).

${ }^{2}$ Cf. Friedrich Schiller, em Cartas sobre a educação estética do homem (apud Duflos, 1999, p. 72 e segs.), e Nietzsche (2001).

${ }^{3}$ Aqui fazemos referência a obras da melhor qualidade, em nosso campo, como Ginzburg (1987), Silva (1997) e Chalhoub (1986).

${ }^{4}$ Sobre o desafio lançado por Levi-Strauss aos historiadores, ver Dosse (2003).

${ }^{5}$ Ver a mais recente simplificação da complexidade do pensamento de Foucault acerca do poder e sua relação com a produção de sujeitos, em Shalins (2004).

"Para um diagnóstico dessa "apavorante" possibilidade de uma história irracionalista, sem sujeito, sem objetividade e sem verdade, ver, por exemplo, Cardoso (1988) e Diehl (1998).

${ }^{7}$ Ver, por exemplo, a entrevista de Carlo Ginzburg em Pallares-Burke (2000, p. 269-307).

${ }^{8}$ Essa é a opinião, por exemplo, de Ronaldo Vainfas (Cardoso; Vainfas, 1997, p.150).

\section{Referências}

CAILLOIS, Roger. Os jogos e os homens. Lisboa: Cotovia, 1990.

CARDOSO, Ciro Flamarion; VAINFAS, Ronaldo. Domínios da história. Rio de Janeiro. Campus, 1997.

CARDOSO, Ciro Flamarion. Ensaios racionalistas. Rio de Janeiro: Campus, 1988.

CHALHOUB, Sidney. Trabalho, lar e botequim. São Paulo: Brasiliense, 1986.

DIEHL, Astor Antônio. Vinho velho em pipa nova: o pós-moderno e o fim da história. Passo Fundo: Ediupf, 1998.

DOSSE, François. A história. Bauru: EDUSC, 2003.

DUFLO, Colas. O jogo: de Pascal a Schiller. Porto Alegre: Artmed, 1999.

FOUCAULT, Michel. História da sexualidade I: a vontade de saber. Rio de Janeiro: Graal, 1977.

História da sexualidade II: o uso dos prazeres. Rio de Janeiro: Graal,

Anos 90, Porto Alegre, v. 11, n. 19/20, p.79-100, jan./dez. 2004 
A História em jogo: a atuação de Michel Foucault...

FOUCAULT, Michel. História da sexualidade III: o cuidado de si. Rio de Janeiro: Graal, 1985. Microfísica do poder. 4 ed. Rio de Janeiro: Graal, 1984a.

GINZBURG, Carlo. O queijo e os vermes. São Paulo: Companhia das Letras, 1987.

HUIZINGA, Johan. Homo ludens. 5 ed. São Paulo: Perspectiva, 2004.

KANT, Emmanuel. Critique de la faculte de juger. Paris: Vrin, 1965.

NIETZSCHE, Friedrich. A Gaia ciência. São Paulo: Companhia das Letras, 2001.

Da utilidade e desvantagem da história para a vida. In: Obras incompletas. 5. ed. São Paulo: Nova Cultural, 1991. V. I.

PALLARES-BURKE, Maria Lúcia Garcia. As muitas faces da história. São Paulo: UNESP, 2000.

PASCAL, Blaise. Pensées. Paris: Seuil, 1963.

SHALINS, Marshal. Esperando Foucault, ainda. São Paulo: Cosac \& Naify, 2004.

SILVA, Eduardo. Dom Oba, o principe do povo. São Paulo: Companhia das Letras, 1997.

Anos 90, Porto Alegre, v. 11, n. 19/20, p.79-100, jan./dez. 2004 